Adrenalektomie; morphologische Beobachtungen im Hypothalamus von adrenalektomierten Hunden und Katzen 343

Aging; time, cells and aging (B) $\quad 324$

Alkaline phosphatase, v. Phosphatases

Allométrie, v. Pancreas

Aminopeptidase, v. Enzymverteilung

Amphibians; quantitative studies on the morphology of respiratory surfaces

in amphibians 296

Anas platyrhynchos, v. Membres, morphogénèse

Anatomie, v. Mikroskopische Anatomie (B)

Anatomy, functional, v. Functional anatomy

Anencephaly, v. Cranioschisis

Angioarchitektur, v. Gefäßanordnung

Anlage der Extremitäten, v. Membres, morphogénèse

-_-; v. Vaginal anlage

Arteries, v. Spinal ganglia

Articulatio cubiti, v. Ellbogen (B)

Articulationes, v. RuffinVs nerve endings

Atlas of descriptive histology (B) 158

Atmungskapillaren, v. Kapillaren

Auris interna, v. Labyrinth

Autoradiograpbic studies and mitotic rate on the derivation and differentia tion of the epithelium in the mouse vaginal anlage 266

-; v. Vaginal anlage, Vascular patterns

Aves, v. Membres, morphogénèse

Axon regeneration; ultrastructural changes of feline ventral horn cells during

the sequences of axon regeneration with relation to their physiological

function 563

Barbus tor; cyclical changes in the testis of the masheer, Barbus tor Ham.

$\operatorname{Buch}(=$ Tor tor) $\quad 461$

Biliaire, vésicule biliaire, v. Gallenblasenschleimhaut

Biométrie, v. Pancreas

Bipedal leaping, v. Leaping, bipedal (Kangaroo)

Bird-embryos, v. Membres, morphogénèse

Blattzottenepithelien, v. Placenta

Blood, v. Hypoxia, Vascular patterns 
Blood supply, v. Kapillardichte, Vascular occlusion, Vascular patterns

Body weight, v. Pancreas, Respiratory surfaces

Bone marrow; studies on hypoxia. (Ill: The differential response of the bone

marrow to primary and secondary hypoxia) 476

-; v. Bones

$1(B)=$ New books - Livres nouveaux - Buchbesprechungen

620

Index rerum

Bones; red cell volumes and vascular patterns in long bones

-; v. Cranioschisis Brain, v. Cerebrum

Buchbesprechungen 158-159, 324

Buds of the extremities, v. Membres, morphogénèse Büschelartige Nervenendigungen, v.

RuffinVs nerve endings

Bulbus olfactorius accessorius bei Insectivoren und Primaten

Bush-like nerve endings, v. Ruffiní's nerve endings Butyrylcholinesterase, v. Cholinesterases

Canard, embryon, v. Membres, morphogénèse

Canís domesticus, v. Hypothalamus

Capillaries, v. Kapillardichte, Vascular patterns

Capillaries, respiratory, calculated in meters per $1 \mathrm{~g}$ body weight, $\mathrm{v}$. Respiratory surfaces

Capsula articularis, v. RuffinVs nerve endings

Cat, v. Felis domestíca, Hypothalamus, Katze

Cavía porcellus, v. Hypoxia

Cavité buccale, vascularisation, v. Respiratory surfaces

Cells; time, cells and aging (B) $\quad 324$

Cerebrum, v. Bulbus olfactorius accessorius, Gehirn des Kaninchens, Hypothalamus

Cerveau, v. Cerebrum

Cervix, v. Lymphknoten

Chat, v. Felis domestíca, Hypothalamus, Katze

Chicks; succinic dehydrogenase in the development of the skeletal muscles

of chicks 434

-; v. Gonades males; Membres, morphogénèse

Chien, v. Hypothalamus

Childrens, v. Ellbogen (B)

Cholinesterases; a histochemical study of ovarian cholinesterases 254

Chorda dorsalis; histologische DifFerenzierung, Anderung des Volumvertei-

lungsmusters und morphogenetische Bedeutung der Chorda dorsalis

während der Embryonal- und Larvalentwicklung von Rana tempo-

raría $\mathrm{L} 104$

Chromatolysis; the effect of vascular occlusion on the chromatolytic cycle

in the spinal ganglia of the rabbit 528

Chromium, radioactive, v. Vascular patterns

Circulation, blood circulation, v. Spinal ganglia

Cobaye, v. Hypoxia

Cæur, v. Heart

Collum, v. Lymphknoten

Coloration, v. Staining 
Comparative anatomy, v. Lymphknoten

Coq, v. Gonades males

Cor, v. Heart

Cordier, Gaston, $\uparrow 157$

Cornu anterius medullae spinalis, v. Axon regeneration

Cou, v. Lymphknoten

Cr51, v. Vascular patterns

Cranioschisis; study of the skull in human cranioschisis

Cranium, v. Cranioschisis

Croissance du pancreas chez le rat pendant la vie post-natale

Index rerum

Croissance, v. Morphogenese

Cyclical changes in the testis of the masheer, Barbus tor Ham. Buch

461

Cytochemistry, v. Axon regeneration, Enzymverteilung, Gallenblasen-schleimhaut,

Histoenzymologie, Ovarium, Phosphatases, Succinic dehydrogenase, Venom gland

Deformations, v. Cranioschisis

Dehydrogenase, succinic, in the development of the skeletal muscles of chicks 434

Descriptive histology, atlas (B) 158

Development of rat ureter, pre- and postnatal; rat ureter, fine structural

changes during its development $\quad 60$

Development, v. Chicks, Cranioschisis, Gonades males, Morphogenese, Pancreas, Vaginal

anlage

Developmental abnormities, v. Craniochisis

Diagnostik, mikroskopische, v. Mikroskopische Anatomie (B)

Differenciation; etude causale de la différenciation la plus précoce de Гébau-

che morphologique des membres. Analyse expérimentale chez les em-

bryons d'oiseaux

80

-; v. Vaginal anlage

Differenzierung, histologische, v. Chorda dorsalis

Difformities, v. Cranioschisis

Dog, v. Hypothalamus

Domestic mammals, v. Haussäugetiere (Lymphknoten)

Dorsal root ganglia, v. Spinal ganglia

Duck, embryo, v. Membres, morphogenese

Ductus semicirculares, v. Labyrinth

Eau douce, poissons d'eau douce, v. Fishes

Ebauche morphologique des membres, v. Membres, morphogenese

Electron microscopical evaluation of the osmic acid-sodium iodide nerve

staining technique on salivary tissue 325

Electron microscope, v. Gallenblasenschleimhaut, Placenta, Ureter

Electrophysiological response, v. Axon regeneration

Ellbogen, kindlicher, Frakturen und Luxationen (B) 324

Embryo, v. Chicks, Cranioschisis, Gonades males, Musculus interosseus dorsalis IV, Rat ureter

Embryonalentwicklung, v. Chorda dorsalis 
Embryons d'oiseaux; etude causale de la différenciation la plus précoce de Гébauche morphologique des membres. Analyse expérimentale chez

les embryons d'oiseaux

80

Enfants, v. Ellbogen (B)

Ente, Embryo, v. Membres, morphogenese

Entwicklung, v. Development, Ontogenesis

Enzymes, v. Ferments, Histoenzymologie

Enzymverteilung, hormonabhängige, in Geweben (IV.: Geschlechtsgebun-

dene Verteilungsunterschiede von Glucose-6-Phosphatase, Succin-

Dehydrogenase und Aminopeptidase in Mäusenieren) 584

Epimys norvegícus; die Lymphknoten und Lymphgefäße der weißen Ratte

(Rattus norvegícus) Berkenhout (= Epimys norvegicus $=$ E. decumanus) 489

Epithelium in the mouse vaginal anlage, v. Vaginal anlage

Epithelzellen, v. Gallenblasenschleimhaut

Epithelzellen der Blattzotten, v. Placenta

Erythrocytes; red cell volumes and vascular patterns in long bones....

622

Index rerum

Extremitates, v. Human hand; Leaping, bipedal (Kangaroo); Membres, morphogénèse Extremity buds, v. Membres, morphogénèse

Face, human, v. Cranioschisis

Färbung, v. Staining

Feinstruktur, v. Felis domestica, Fine structural changes, Fine structure,

Gallenblasenschleiinhaut, Nerve staining, Placenta

Felis domestica; ultrastructural changes of feline ventral horn cells during the sequences of axon regeneration with relation to their physiological

function 563

-; v. Hypothalamus, Katze

Femur, v. Vascular patterns

Ferments, v. Cholinesterases, Gonades males, Hormonabhängige Enzymver-teilung in Geweben, Phosphatases, Succinic dehydrogenase

Fetus, v. Foetus

Fine structural changes of the rat ureter during its development

60

Fine structure of the porcine placental barrier $\quad 334$

Fine structure, v. Felis domestica, Gallenblasenschleimhaut, Nerve staining, Placenta

Fishes; on the morphology of the labyrinth in some sweet-water fishes . . 445

-; v. Barbus tor

Foetus, v. Chicks, Cranioschisis, Embryonalentwicklung, Gonades males, Museums interosseus

dorsalis IV, Rat ureter

Foie, v. Liver

Fortpflanzungsphysiologie, v. Mammalian reproduction (B)

Fowl, embryo, v. Membres, morphogénèse

Frakturen und Luxationen am kindlichen Ellbogen (B) 324

Frog, v. Rana temporaria 
Functional anatomy; some notes on the functional anatomy of Macropus gíganteus Zimm., with general remarks on the mechanics of bipedal leaping 418

Gallenblasenschleimhaut des Menschen und der Katze, Ultrastruktur und Histochemie 606

Gallus domesticus; observations histoenzymologiques sur les gonades males de Gallus domesticus pendant le développement 402

—; v. Chicks; Membres, morphogénèse

Ganglia, intramural; neurons of intramural ganglia of the heart in its hyper-

function and hypertrophy 161

Ganglia, spinal ganglia; effect of vascular occlusion on the chromatolytic

cycle in the spinal ganglia of the rabbit 528

Ganglions lymphatiques, v. Lymphknoten, Rattus norvegícus

Gefäßanordnung und Kapillardichte im Gehirn des Kaninchens 539

Gefäße, v. Respiratory surfaces, Vascular occlusion, Vascular patterns

Gehirn, v. Cerebrum

Gehirnschädel, v. Cranioschisis

Gehirn des Kaninchens, Gefäßanordnung und Kapillardichte

Gerontologie, v. Aging (B)

Geschlechtsunterschiede; hormonabhängige Enzymverteilung in Geweben

(IV.: Geschlechtsgebundene Verteilungsunterschiede von Glucose-6-

Phosphatase, Succin-Dehydrogenase und Aminopeptidase in Mäusenie-

ren) 584

Index rerum 623

Gesichtsschädel, v. Cranioschisis Giftdrüse, v. Venom gland Glande à vénin, v. Venom gland

Glandulae submandibulares, v. Salivary tissue Glandulae suprarenales, v. Hypothalamus

Glucose-6-Phosphatase, v. Enzymverteüung

Gonades males de Gallus domesticus, observations histoenzymologiques pen

dant le développement $\quad 402$

Gonads, v. Cyclical changes Grenouille, v. Rana temporaria Growth, v. Morphogenese, Pancreas

Guinea-pig, v. Hypoxia

H3 (H3-thymidine), v. Vaginal anlage

Halslymphknoten; die vergleichende Anatomie der Pharynx- und Hals-

lymphknoten der Haussäugetiere und des Menschen (Homologisierung

und Nomenklaturvorschlag) 21

Hand, human; structural analysis of the fourth dorsal interosseus of the

human hand 176

Hartman, Carl G., bibliography of his scientific publications, v. Mammalian reproduction (B)

Haussäugetiere; die vergleichende Anatomie der Pharynx- und Halslymph

knoten der Haussäugetiere und des Menschen (Homologisierung und

Nomenklaturvorschlag)

21

Heart; neurons of intramural ganglia of the heart in its hyperfunction and

hypertrophy 161

Hepar, v. Liver

Herz, v. Heart

Histochemical study on the distribution of alkaline and acid phosphatase in 
liver of different classes of vertebrates

Histochemical study of ovarian cholinesterases

Histochemie und Ultrastruktur der Gallenblasenschleimhaut des Menschen

und der Katze 606

Histochemistry, v. Axon regeneration, Enzymverteüung, Histoenzymologie, Succinic

dehydrogenase, Venom gland

Histoenzymologie; observations histoenzymologiques sur les gonades males

de Gallus domesticus pendant le développement 402

Histologie und mikroskopische Anatomie des Menschen mit Berücksichti-

gung der Histophysiologie und der mikroskopischen Diagnostik

(4.Aufl.)(B) 158

Histologische Differenzierung, Änderung des Volumenverteilungsmusters

und morphogenetische Bedeutung der Chorda dorsalis während der

Embryonal- und Larvalentwicklung von Rana temporaria L 104

Histology, descriptive, atlas (B) 158

Histophysiologie, v. Histologie (B)

Hoden, v. Testes

Homme, v. Histologie (B), Human hand, Mensch

Homologisierung (vergleichende Anatomie der Pharynx- undJ,Halslymph-knoten), v.

Lymphknoten

Hormonabhängige Enzymverteilung in Geweben (IV.: Geschlechtsgebundene

Verteilungsunterschiede von Glucose-6-Phosphatase, Succin-Dehydro-

genase und Aminopeptidase in Mäusenieren) , 584

Hühnchen, v. Chicks

624

Index rerum

Huhn, v. Gallus domestícus

Human cranioschisis; study of the skull in human cranioschisis

Human hand; structural analysis of the fourth dorsal interosseus of the

human hand 176

Hund; morphologische Beobachtungen im Hypothalamus von adrenalekto-

mierten Hunden und Katzen 343

Hyperfunction of the heart, v. Ganglia, intramural

Hypertrophy of the heart, v. Ganglia, intramural

Hypothalamus; morphologische Beobachtungen im Hypothalamus von

adrenalektomierten Hunden und Katzen 343

Hypoxia, studies. (III.: The differential response of the bone marrow to

primary and secondary hypoxia) $\quad 476$

Indisches Panzernashorn, v. Panzernashorn, indisches

Insectivoren; der Bulbus olfactorius accessorius bei Insectivoren und Pri-

maten 215

Intramural ganglia of the heart, v. Ganglia, intramural Isotope, radioaktive, v. Vaginal anlage,

Vascular patterns

Jahreszeiten, v. Cyclical changes

Joints of some mammals; differences in the structure and variability of spray

like nerve endings in the joints of some mammals 568 
Kangaroo, v. Macropus giganteus

Kaninchen; Gefäßanordnung und Kapillardichte im Gehirn des Kaninchens 539

-; v. Rabbit

Kapillardichte und Gefäßanordnung im Gehirn des Kaninchens

Kapillaren, v. Vascular patterns

Kapillaren (Atmungskapillaren) pro g Körpergewicht in Metern, v. Respiratory surfaces

Katze; morphologische Beobachtungen im Hypothalamus von adrenalekto

mierten Hunden und Katzen 343

-; zur Ultrastruktur und Histochemie der Gallenblasenschleimhaut des

Menschen und der Katze 606

-; v. Felís domestíca

Kerne (Zellkerne), v. Axon regeneration, Chromatolysis

Kidney, v. Enzymverteilung

Kind, v. Ellbogen (B)

Knochen, v. Cranioschisis

Knochenmark, v. Hypoxia, Vascular patterns

Körpergewicht, v. Pancreas, Respiratory surfaces

Labyrinth, morphology, in some sweet-water fishes 445

Lapin, v. Gehirn des Kaninchens, Rabbit

Larvalentwicklung, v. Chorda dorsalis

Leaping, bipedal; some notes on the functional anatomy of Macropus giganteus Zimm., with general remarks on the mechanics of bipedal leaping 418

Leber, v. Liver

Ligature des artères, v. Spinal ganglia

Limb-buds, v. Membres, morphogénèse

Liver; histochemical study on the distribution of alkaline and acid phos-

phatase in liver of different classes of vertebrates 53

Livres nouveaux 158-159,324

Index rerum 625

Locomotion, saltatorial, v. Leaping, bipedal (Kangaroo)

Long bones, v. Vascular patterns

Lungs, vascular supply, v. Respiratory surfaces

Luxationen und Frakturen am kindlichen Ellbogen (B) 324

Lymphgefäße, v. Lymphknoten

Lymphknoten; die vergleichende Anatomie der Pharynx- und Halslymph-

knoten der Haussäugetiere und des Menschen (Homologisierung und

Nomenklaturvorschlag)

21

Lymphknoten und Lymphgefäße der weißen Ratte (Rattus norvegicus) Ber-

kenhout (= Epímys norvegicus $=$ E.decumanus) 489

Macropus giganteus; some notes on the functional anatomy of Macropus

giganteus Zimm., with general remarks on the mechanics of bipedal

leaping 418

Mäusenieren; hormonabhängige Enzymverteilung in Geweben (IV.: Ge-schlechtsgebundene Verteilungsunterschiede von Glucose-6-Phospha-tase, Succin-Dehydrogenase und

Aminopeptidase in Mäusenieren) . . 584

Main, v. Human hand 
Malformations, v. Cranioschisis

Mammalia, v. Haussäugetiere (Lymphknoten)

Mammalian reproduction; fifty years of research on mammalian reproduction

(with a bibliography of the scientific publications of Carl G. Hartman)

(B) 159

Mammals; differences in the structure and variability of spray-like nerve

endings in the joints of some mammals 568

Mammifères domestiques, v. Haussäugetiere (Lymphknoten)

Man, v. Gallenblasenschleimhaut, Histologie (B), Human cranioschisis, Human hand

Manus, v. Human hand

Masheer (= indian fish); cyclical changes in the testis of the masheer, Bar-

bus tor Ham.Buch 461

Maus, v. Mäusenieren, Mouse

Medulla ossium, v. Hypoxia, Vascular patterns

Medulla spinalis; ultrastructural changes of feline ventral horn cells during

the sequences of axon regeneration with relation to their physiological

function 563

-; v. Chromatolysis

Meerschweinchen, v. Hypoxia

Membres, morphogénèse; etude causale de la différenciation la plus précoce

de Гébauche morphologique des membres. Analyse expérimentale chez

les embryons d'oiseaux

80

Membrum inferius, v. Leaping, bipedal (Kangaroo)

Membrum superius, v. Human hand

Mensch; zur Ultrastruktur und Histochemie der Gallenblasenschleimhaut

des Menschen und der Katze 606

-; v. Histologie (B), Human hand

Methode, v. Osmic acid-sodium nerve staining

Meyer, Pierre, $† \quad 157$

Mice, v. Mäusenieren, Mouse

Microautoradiography, v. Vaginal anlage, Vascular patterns

Microradiography (=X-ray absorption), v. Axon regeneration

Microscope électronique, v. Gallenblasenschleimhaut, Nerve staining, Placenta, Placental

barrier, Ureter

626

Index rerum

Mikroskopische Anatomie und Histologie des Menschen mit Berücksich-

tigung der Histophysiologie und der mikroskopischen Diagnostik

(4.Aufl.)(B) 158

Mißbildung, v. Cranioschisis

Mitotic rate and autoradiographic studies on the derivation and differentia

tion of the epithelium in the mouse vaginal anlage 266

Moelle épinière, v. Axon regeneration, Chromatolysis

Moelle osseuse, v. Hypoxia, Vascular patterns 
Morphogénèse; etude causale de la différenciation la plus précoce de Гébauche morphologique des membres. Analyse expérimentale chez les embryons

d'oiseaux 80

-; histologische Differenzierung, Anderung des Volumverteilungsmusters

und morphogenetische Bedeutung der Chorda dorsalis während der

Embryonal- und Larvalentwicklung von Rana temporaria L 104

Mouse; mitotic rate and autoradiographic studies on the derivation and

differentiation of the epithelium in the mouse vaginal anlage .... 266

—; v. Mäusenieren

Mouth, vascular supply, v. Respiratory surfaces

Mucosa of the gall bladder, v. Gallenblasenschleimhaut

Mus musculus, v. Mäusenieren, Mouse

Muscles, skeletal, of chicks; succinic dehydrogenase in the development of

the skeletal muscles of chicks 434

Musculus interosseus dorsalis IV; structural analysis of the fourth dorsal

interosseus of the human hand 176

Nachrufe $\quad 157$

Neck, v. Lymphknoten

Necrologies 157

Nerve endings, spray-like; differences in the structure and variability of spray-like nerve endings in the joints of some mammals 568

Nerve staining; electron microscopical evaluation of the osmic acid-sodium iodide nerve staining technique on salivary tissue 325

Nerven (Nervensystem, Zentralnervensystem), v. Axon regeneration, Bulbus

olfactorius accessorius, Chromatolysis, Gehirn des Kaninchens, Hypo-

thalamus, Nerve endings, Nerve staining, Neurons Neurons of intramural ganglia of the heart in

its hyperfunction and hyper-

rophy 161

New books 158-159,324

Niere, v. Enzymverteilung

Nodi lymphatici, v. Lymphknoten

Nomenklaturvorschlag (Nomina anatomica veterinaria), v. Halslymphkno-

ten Notochord, v. Chorda dorsalis Nuclei, v. Axon regeneration, Chromatolysii

Obituaries 157

Oiseaux, embryons, v. Membres, morphogénèse

Olfactory bulb, v. Bulbus olfactorius accessorius

Ontogenesis, v. Chicks, Chorda dorsalis, Cranioschisis, Différenciation,

Gonades males, Musculus interosseus dorsalis IV, Rat ureter, Vaginal

anlage Ophidia, v. Venom gland

Index rerum 627

Organogenesis, v. Gonades males

Organum stato-acusticum, v. Labyrinth

Oryctolagus cunículus, v. Gehirn des Kaninchens, Rabbit

Os, v. Bones, Cranioschisis 
Osmic acid-sodium iodide nerve staining; electron microscopical eva luation of the osmic acid-sodium iodide nerve staining technique on salivary tissue 325

Ovarium; a histochemical study of ovarian cholinesterases 254

Oxygen, v. Hypoxia

Pancreas; la croissance du pancreas chez le rat pendant la vie post-natale . 283 Panzernashorn, indisches; zur Ultrastruktur der Blattzottenepithelien in der

Placenta des indischen Panzernashorns (Rhinoceros unícornis L.) . 593 Peau, vascularisation, v. Respiratory surfaces Perissodactyla, v. Panzernashorn Pharynxlymphkonten; die vergleichende Anatomie der Pharynx- und Hals-

lymphknoten der Haussäugetiere und des Menschen (Homologisierung

und Nomenklaturvorschlag) 21

Phosphatases; histochemical study on the distribution of alkaline and acid

phosphatase in liver of different classes of vertebrates

Physiologie (Histophysiologie), v. Histologie (B)

Pig, v. Placental barrier

Pisces, v. Barbus tor, Labyrinth

Placenta; zur Ultrastruktur der Blattzottenepithelien in der Placenta des

indischen Panzernashorns (Rhinoceros unícornís L.) 593

Placental barrier of the pore, fine structure 334

Poids corporel, v. Pancreas, Respiratory surfaces Poissons, v. Barbus tor, Labyrinth

Porcine placental barrier, fine structure $\quad 334$

Poulet, v. Chicks; Gonades males, Membres, morphogénèse

Poumons, vascularisation, v. Respiratory surfaces

Primaten; der Bulbus olfactorius accessorius bei Insectivoren und Primaten 215

Primary hypoxia, v. Hypoxia

Proteins (in ventral horn cells), v. Axon regeneration

Rabbit; the effect of vascular occlusion on the chromatolytic cycle in the spinal ganglia of the rabbit 528

-; v. Gehirn des Kaninchens

Radiochromium, v. Vascular patterns

Radiography (microautoradiography), v. Vaginal anlage, Vascular patterns Radiography (microradiography: X-ray absorption), v. Axon regeneration Rana temporaria; histologische Differenzierung, Anderung des Volumverteilungsmusters und morphogenetische Bedeutung der Chorda dorsalis während der Embryonal- und Larvalentwicklung von Rana temporaria L $\quad 104$

Rat; la croissance du pancreas chez le rat pendant la vie post-natale . . 283

-; v. Rattus norvegicus, Vascular patterns

Rat ureter; fine structural changes during its development 60

Rattus norvegicus; die Lymphknoten und Lymphgefäße der weißen Ratte

(Rattus norvegicus) Berkenhout (= Epimys norvegicus $=$ E. decumanus) 489

Rayons X, absorption, v. Axon regeneration

Receptors, v. RuffinVs nerve endings

Red cell volumes and vascular patterns in long bones

628 


\section{Index rerum}

Regeneration, v. Axon regeneration

Regio metacarpo-phalangea, v. Musculus interosseus dorsalis IV

Ren, v. Enzymverteilung

Reproduction, mammalian, v. Mammalian reproduction (B)

Reproductive organs, v. Gonades males

Respiratory surfaces; quantitative studies on the morphology of respiratory

surfaces in amphibians 296

Rhinencephalon, v. Bulbus olfactorius accessorius

Rhinoceros unícornís; zur Ultrastruktur der Blattzottenepithelien in der

Placenta des indischen Panzernashorns (Rhinoceros unícornís L.) . 593

Rhythms, v. Cyclical changes

Riesenkänguruh, v. Macropus gíganteus

Röntgenstrahlen, Absorption, v. Axon regeneration

Rückenmark, v. Axon regeneration, Chromatolysis

RuffinVs nerve endings; differences in the structure and variability of spray

like nerve endings in the joints of some mammals 568

Säugetiere (Lymphknoten), v. Haussäugetiere

Salivary tissue; electron microscopical evaluation of the osmic acid-sodium

iodide nerve staining technique on salivary tissue $\quad 325$

Sauerstoff, v. Hypoxia

Saut, progression par saut, v. Leaping, bipedal (Kangourou)

Schädel, v. Cranioschisis

Schlangen, v. Venom gland

Schleimhaut der Gallenblase; zur Ultrastruktur und Histochemie der Gallenblasenschleimhaut des Menschen und der Katze $\quad 606$

Schwein, v. Placental barrier

Seasonal changes, v. Cyclical changes

Secondary hypoxia, v. Hypoxia

Sensory nerve endings, $v$. RuffinVs nerve endings

Serpents, v. Venom gland

Sex differences, v. Geschlechtsunterschiede

Sexual cycle, v. Cyclical changes

Skeletal muscles of chicks, development, succinic dehydrogenase 434

Skeleton of the cranium, v. Cranioschisis

Skin, vascular supply, v. Respiratory surfaces

Skull; study of the skull in human cranioschisis

Snake venom gland, v. Venom gland

Souris, v. Mäusenieren, Mouse

Sow, v. Placental barrier

Spermatogenesis, v. Cyclical changes

Spinal cord, v. Axon regeneration

Spinal ganglia; effect of vascular occlusion on the chromatolytic cycle in the spinal ganglia of the rabbit 528

Spray-like nerve endings, v. RuffinVs nerve endings

Sprungbewegung, v. Leaping, bipedal (Känguruh) 
Staining, nerve staining; electron microscopical evaluation of the osmic acid-sodium iodide nerve staining technique on salivary tissue . . . 325

Statistische Auswertung, v. Hypoxia, Mitotic rate, Pancreas

Structural analysis of the fourth dorsal interosseus of the human hand . 176

Submicroscopical structure, v. Gallenblasenschleimhaut, Nerve staining, Placenta, Placental

barrier, Ultrastructural changes..., Ureter

Succinic dehydrogenase in the development of the skeletal muscles of chicks 434

Index rerum

629

-; v. Enzymverteilung

Süßwasser-Fische, v. Fishes

Surrénales, v. Hypothalamus

Sus scrofa, v. Placental barrier

Sweet-water fishes, v. Fishes

Systema lymphaticum, v. Rattus norvegícus

Technique, v. Osmic acid-sodium nerve staining

Teleost fish, v. Barbus tor

Teratologie, v. Cranioschisis

Terminaisons nerveuses, v. RuffinVs nerve endings

Testes; cyclical changes in the testis of the masheer, Barbus tor Ham.Buch. 461

-; v. Gonades males

Thymidine-H3, v. Vaginal anlage

Tibia, v. Vascular patterns

Time, cells and aging (B) $\quad 324$

Tor tor, v. Barbus tor

Tritium, v. Vaginal anlage

Tunica mucosa vesicae felleae, v. Gallenblasenschleimhaut

TJltrastructural changes of fehne ventral horn cells during the sequences of

axon regeneration with relation to their physiological function . . 563

Ultrastructure, v. Nerve staining, Placental barrier, Ureter

Ultrastruktur der Blattzottenepithelien in der Placenta des indischen Pan-

zernashorns (Rhinoceros unicornís L.)

593

Ultrastruktur und Histochemie der Gallenblasenschleimhaut des Menschen

und der Katze 606

Unterbindung von Arterien, v. Spinal ganglia

Ureter, rat ureter; fine structural changes during its development ....60

Vaginal anlage; mitotic rate and autoradiographic studies on the derivation

and differentiation of the epithelium in the mouse vaginal anlage . . 266

Vaisseaux, v. Gefäßanordnung, Respiratory surfaces, Vascular occlusion, Vascular patterns

Vasa lymphatica, v. Rattus norvegicus

Vascular occlusion, effect on the chromatolytic cycle in the spinal ganglia of

the rabbit $\quad 528$

Vascular patterns and red cell volumes in long bones

Vascular supply of skin, in the lungs and mouth, v. Respiratory surfaces

Vascularisation, v. Gehirn des Kaninchens, Vascular patterns

Venom gland of Vipera palaestinae, with comments on the glands of some 
other viperines 365

Ventral horn cells of cat, v. Axon regeneration

Vergleichende Anatomie, v. Lymphknoten

Vertebrata; histochemical study on the distribution of alkaline and acid phos-

phatase in liver of different classes of vertebrates 53

Vesica fellea, v. Gallenblasenschleimhaut

Vessels, v. Gefäßanordnung, Respiratory surfaces, Vascular occlusion, Vascular patterns

Vie post-natale, v. Pancreas, Vaginal anlage

Vipera palaestinae; the venom gland of Vipera palaestinae with comments on

the glands of some other viperines 365

Vögel, Embryonen, v. Membres, morphogénèse

630

Index rerum

Volumenverteilungsmuster der Chorda dorsalis; histologische DifFerenzie-

rung, Änderung des Volumverteilungsmusters und morphogenetische

Bedeutung der Chorda dorsalis während der Embryonal- und Larval-

entwicklung von Rana temporaría L 104

Vorderhornzellen, v. Axon regeneration

Wachstum, v. Morphogenese, Pancreas Weiße Ratte, v. Rattus norvegícus

X-rays, absorption, v. Axon regeneration

Zellen, v. Cells (B)

Zellkerne, v. Axon regeneration, Chromatolysis

Zellteilungen, v. Mitotic rate

Zirkulation (Blutzirkulation), v. Spinal ganglia

New books - Livres nouveaux - Buchbesprechungen

Bucher, 0.: Histologie und mikroskopische Anatomie des Menschen mit

Berücksichtigung der Histophysiologie und der mikroskopischen Dia-

gnostik (4.Aufl.) (Verlag Huber, Bern/Stuttgart 1965) (Ref.: G.Glim-

stedt) 158

Hartman, C.G.: Fifty years of research on mammalian reproduction, with a

bibliography of the scientific publications of Carl G. Hartman (Ed.: R. F.

Vollman) (Publ. health bibliography ser. Nr. 57; published by the U.S.

Department of Health, Education, and Welfare 1965) (Ref.: E. Witschi) 159 Morger, JR.:

Frakturen und Luxationen am kindlichen Ellbogen (Bibl. pae-

diatrica fasc.83) (S.Karger Verlag Basel/New York 1965) (Ref.: J.

Müller) 324

Reith, E.J. and Ross, M.H.: Atlas of descriptive histology (Hoeber Medical

Division, Harper and Row, New York/London 1965) (Ref.: D.E.

Kelly) 158

Strehler, B.L.: Time, cells, and aging (Academic Press Inc., New York 1962)

(Ref.: 0.Bucher) $\quad 324$ 